\title{
GENETIC RESPONSE TO THE SEQUENCE OF TWO ENVIRONMENTS
}

\author{
LOUIS LEVINE \\ Biology Department, The City College of the City University of New York, \\ New York 31, N.Y. \\ and \\ LEIGH VAN VALEN \\ Department of Vertebrate Paleontology, American Museum of Natural History, \\ New York, 24, N.Y.
}

Received 4.vi.64

Studies on chromosomal polymorphism in Drosophila pseudoobscura have shown that the relative fitness of the different gene sequences varies under different temperature conditions. At $25^{\circ} \mathrm{C}$., populations composed of the gene sequences Arrowhead (AR) and Chiricahua ( $\mathrm{CH}$ ) establish a stable polymorphic system with characteristic equilibrium frequencies of 25-30 per cent. $\mathrm{CH}$ and correspondingly 75-70 per cent. AR (Dobzhansky, 1948; Levine, 1955; Beardmore, Dobzhansky and Pavlovsky, I96o; Mourad, I962; Strickberger, I963). At slightly lower temperatures, there appears a partly non-determinate situation. In one set of experiments at $22^{\circ} \mathrm{C}$., $\mathrm{CH}$ appeared to have established itself at the characteristic 25-30 per cent. level. In a second set of experiments at $22^{\circ} \mathrm{C}$., and in experiments at $17-27^{\circ}$ C. fluctuating temperatures, $\mathrm{CH}$ tended toward elimination (Van Valen, Levine and Beardmore, 1962 ). In the populations in which $\mathrm{CH}$ tended toward elimination, the direction of the selection process became evident when the populations were one year old. At that time, subsamples of four populations were taken and placed in population cages at $25^{\circ} \mathrm{C}$. In three of the four derived populations, $\mathrm{CH}$ continued to tend toward elimination (Van Valen, Levine and Beardmore, I 962 ). The inability of these three derived populations to establish and maintain the chromosomal polymorphism so characteristic at $25^{\circ} \mathrm{C}$. has led us to study the effects of reversing the sequence of temperatures.

An experimental population, \# 173 , containing $\mathrm{AR}$ and $\mathrm{CH}$, has been maintained at $25^{\circ} \mathrm{C}$. for some seven years (Beardmore, Dobzhansky and Pavlovsky, I96o; M. Druger, personal communication). This population was started in January, I957, in a wooden cage, with initial frequencies of 80 per cent. $\mathrm{CH}$ and 20 per cent. AR. In a little more than a year and a half, the population reached the expected frequency of 25-30 per cent. $\mathrm{CH}$. In August, I96I, a subsample was taken from this population and placed in a lucite population cage. The methods used have been described elsewhere (Van Valen, Levine and Beardmore, r 962 ). The population cage containing the subsample was placed in a $22^{\circ} \mathrm{C}$. incubator. Eggs from both populations were sampled at varying intervals, 300 chromosomes being examined at each sample. The data are presented in table $I$. It can be seen that the frequency of $\mathrm{CH}$ dropped initially in both populations. In population \# I 73, CH decreased to I9 per cent., a frequency which was maintained for one year. The most recent sample shows that $\mathrm{CH}$ has returned to its characteristic level. In contrast to the parental population, 
population \# I $73-22^{\circ} \mathrm{C}$. appears to be in the process of slowly eliminating CH.

Based on earlier findings, these results were unexpected. In previous studies it was found that populations maintained at $22^{\circ} \mathrm{C}$. or $17-27^{\circ} \mathrm{C}$. fluctuating temperatures for only one year (about I I generations) tended to lose their ability to respond to a $25^{\circ} \mathrm{C}$. environment. Reversing the sequence of temperatures gives different results. A population maintained

TABLE I

Percentage $\mathrm{CH}$ in population $\# \mathrm{I} 73$ and its derivative

\begin{tabular}{|c|c|c|c|c|}
\hline \multicolumn{2}{|c|}{ \# I 73} & \multirow{2}{*}{ Dates } & \multicolumn{2}{|c|}{$\# 173^{-22^{\circ} \mathrm{C} .}$} \\
\hline Month & $\begin{array}{c}\text { Percentage } \\
\mathrm{CH}\end{array}$ & & Month & $\begin{array}{c}\text { Percentage } \\
\text { CH }\end{array}$ \\
\hline o & $80 \cdot 0$ & Jan. 1957 & & \\
\hline \multicolumn{5}{|c|}{$\begin{array}{l}\text { Data for this period } \\
\text { reported by Beard- } \\
\text { more } \text { et al., } 1960\end{array}$} \\
\hline 26 & $25 \cdot 3$ & Mar. 1959 & & \\
\hline 34 & $28 \cdot 0$ & Nov. 1959 & & \\
\hline $\begin{array}{l}46 \\
53\end{array}$ & $\begin{array}{l}25.3 \\
25.9\end{array}$ & $\begin{array}{l}\text { Nov. } 1960 \\
\text { June } 1961\end{array}$ & & \\
\hline 55 & - & Aug. $196 \mathrm{I}$ & \multicolumn{2}{|c|}{ started from $\# \mathbf{I} 73$} \\
\hline - & - & Jan. 1962 & 5 & $22 \cdot 7$ \\
\hline 62 & 19.0 & Mar. 1962 & - & - \\
\hline - & - & May 1962 & 9 & 10.7 \\
\hline - & - & Aug. $19^{62}$ & 12 & 7.7 \\
\hline - & $\overrightarrow{10 \cdot 0}$ & Jan. $\quad 1963$ & 17 & $9 \cdot 3$ \\
\hline 74 & $19 \cdot 0$ & Mar. 1963 & $\overline{22}$ & $\overline{5 \cdot 0}$ \\
\hline- & - & $\begin{array}{l}\text { June } 1903 \\
\text { Aug. } 1963\end{array}$ & 24 & $6 \cdot 3$ \\
\hline $8 \mathrm{I}$ & $26 \cdot 3$ & Oct. 1963 & 26 & $7 \cdot 0$ \\
\hline - & - & Jan. 1964 & 29 & $4 \cdot 3$ \\
\hline
\end{tabular}

at $25^{\circ} \mathrm{C}$. for $4 \frac{1}{2}$ years (over 50 generations) can still respond to a $22^{\circ} \mathrm{C}$. environment as seen in the elimination or near elimination of $\mathrm{CH}$. This finding indicates that the effects on a population of a series of environments may depend on the order in which the environments are experienced. These results also support our earlier findings (Van Valen, Levine and Beardmore, I962) that $22^{\circ} \mathrm{C}$. represents an environment in which chromosomal polymorphism may be eliminated.

Acknowledgments.-These experiments were conducted in the laboratory of Professor Th. Dobzhansky at Columbia University; we gratefully acknowledge his interest, encouragement and hospitality. During this time, one of us (L.V.) was the recipient of a Boese Postdoctoral Fellowship from Columbia University. During its long history, population \#I73 was maintained at various times by $\mathrm{Mrs} O$. Pavlovsky, Dr A. M. Mourad and Dr M. Druger. The authors also thank Dr Druger for his recent sampling of population \#I 73 and for his permission to use the datum in this paper. 


\section{REFERENCES}

BEARDMORE, J. A., DOBZHANSKy, TH., AND PAVlovSky, O. A. I96o. An attempt to compare the fitness of polymorphic and monomorphic experimental populations of Drosophila pseudoobscura. Heredity, I4, 19-33.

DOBzHANsKy, TH. 1948. Genetics of natural populations. XVIII. Experiments on chromosomes of Drosophila pseudoobscura from different geographic regions. Genetics, 33, 588-602.

LeVine, L. 1955. Genotypic background and heterosis in Drosophila pseudoobscura. Genetics, $40,832-849$.

MOURAD, A. M. 1962. Effects of irradiation in genetically coadapted systems. Genetics, 47, 1647-1662.

STRIGKBERGER, M. W. 1963. Evolution of fitness in experimental populations of Drosophila pseudoobscura. Evolution, 17, 40-55.

VAN VAlen, L., LeVine, L., AND BeARDMORE, J. A. I962. Temperature sensitivity of chromosomal polymorphism in Drosophila pseudoobscura. Genetica, 33, I13-127.

\section{INTERRELATIONSHIP OF CHIASMA FREQUENCY IN BIVALENTS IN DACTYLIS GLOMERATA sUbSP. LUSITANICA}

S. S. SHAH

Botany Division, I.A.R.I., New Delhi 12, India

Received ro.vi. 64

THE chiasma frequency in one bivalent is in many cases not independent of chiasma frequency in other bivalents and often the bivalents compete with each other (Darlington, I933; Mather and Lamm, 1935; Morgan et al., 1933; Jain and Maherchandani, 1961). Mather (1936) examined this relation in 27 species and hybrids in both plants and animals belonging to diverse groups and he observed that while a positive correlation of chiasma frequency in various bivalents occurs in some cases, a negative correlation occurs more often. He generalises from the data that after a certain level of chiasma formation bivalents must compete and this will result in a negative correlation.

Some plants with supernumeraries were obtained in Dactylis glomerata subsp. lusitanica. These supernumeraries are heteropycnotic and they pair among themselves (Shah, I 963). The normal complement in this subspecies consist of 14 chromosomes. The seven pairs of homologues have no obvious size differences at meiosis. A study of "competition" in plants having supernumeraries could give information with respect to the effect of the presence of heterochromatin in the cell on competition. Also such material allows one to study the effect of the chiasma frequency in the supernumeraries on the chiasma frequency in the normal set. The author has not come across any similar studies in the literature, though extensive work has been done on supernumeraries both in plants and animals (see reviews by Müntzing, I958 and by White, 1954). In the present paper data are presented on the interrelationships of chiasma frequency in the bivalents of the normal set in plants with 2 supernumeraries. Data for the same 